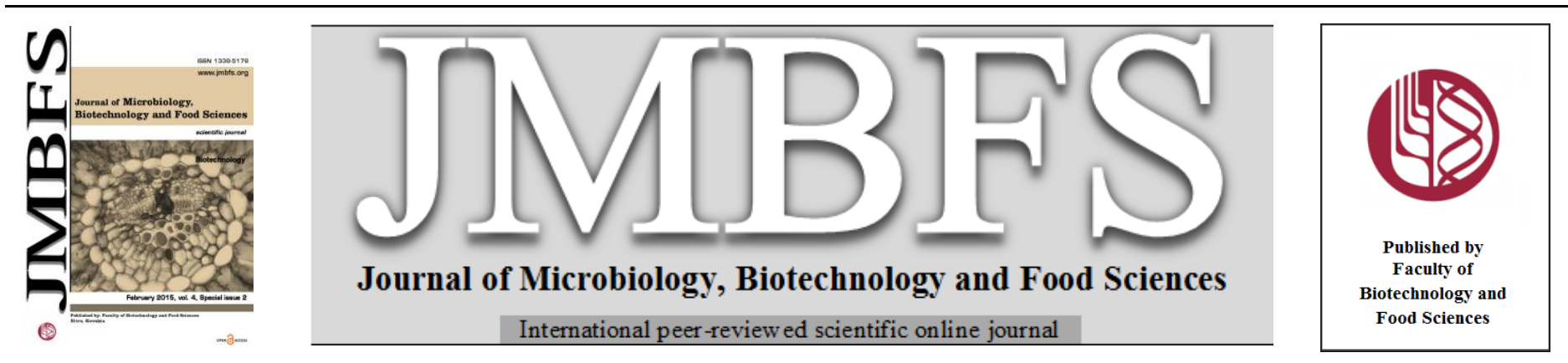

\title{
GENETIC DIVERSITY OF GLU-1 IN EUROPEAN WHEAT GENETIC RESOURCES AND VARIETIES
}

\author{
Tímea Kut'ka Hlozáková ${ }^{1 *}$ Edita Gregová2, Zdenka Gálovál \\ Address(es): Ing.Tímea Kut'ka Hlozáková \\ ${ }^{1}$ Slovak University of Agriculture, Faculty of Biotechnology and Food Science, Tr. A. Hlinku 2, 94976 Nitra, Slovak Republic \\ ${ }^{2}$ National Agriculture and Food Centre, Research Institute of Plant Production, Bratislavská cesta 122, 92101 Pieštany, Slovak Republic
}

*Corresponding author: xhlozakova@is.uniag.sk

doi: 10.15414/jmbfs.2015.4.special2.23-25

\section{ARTICLE INFO}

Received 10. 12. 2014

Revised 16. 12. 2014

Accepted 9.1.2015

Published 2. 2. 2015

\section{Regular article}

open $\partial_{\text {ACCESS }}$

\section{INTRODUCTION}

Wheat kernels, also called grains, have three main parts: the endosperm, the germ, and the brain. The endosperm of wheat is mainly comprised of starch (approximately $70 \%$ ) and proteins (approximately $10-15 \% \mathrm{dw}$ ). In the latter component, the storage proteins $(80 \%)$ are comprised of gliadins (40\%), high molecular weight glutenin subunits (HMW-GS, 10\%) and low molecular weight glutenin subunits (LMW-GS, 30\%). The HMW glutenin subunits (GS) of wheat proteins are quantitatively minor, but functionally an important group of gluten proteins in the process of bread making. The genes controlling synthesis of glutenins are located in hexaploid wheat (Triticum aestivum L.) at the long arm of chromosomes 1A, 1B, and 1D, genes controlling synthesis of HMW - GS are located at the loci $G l u-1 A, G l u-1 B$ and $G l u-1 D$ (Payne, 1987).

The relationships between HMW-GS and bread making quality were studied as the presence and absence of subunits (Payne, 1987) or as the quantity of one subunit related to quality (Weegels $\boldsymbol{e t} \mathbf{a l}$. , 1996) and the additivity or combined role of HMW- and LMW-GS in improving bread making quality (Payne, 1987; Gupta et al., 1989). Other grain components, such as lipids and carbohydrates also affect bread making quality, possibly by interacting with the gluten proteins Correlations and genetic studies of HMW-GS (Pogna et al., 1986; Payne, 1987) established subunits with both positive $(5+10)$ and negative $(2+12)$ effects on bread making quality. Other allelic variant pairs showed similar results (Payne, 1987). In general, a null at $G l u-1 A$ locus, subunit $6+8$ encoded at $G l u-1 B$ and $2+12$ at Glu-D1 are negatively related with the quality parameters (Weegels $\boldsymbol{e t}$ al., 1996). A scoring system for HMW-GS has been developed (Pogna and Mellini, 1986; Payne, 1987) as the sum of the contributions of each of the three HMW-GS loci. However, the HMW-GS score has higher influence in some sets of wheat than in others (MacRitchie et al., 1990; Bedõ et al., 1995). Nevertheless, reference to HMW-GS composition has proved valuable in the segregation of lines in the process of breeding for specific quality targets (Weegels et al., 1996; Cornish et al., 1999) and as indicators of quality when only small amounts of the material are available and fast quality prediction is necessary (Weegels et al., 1996).

The objective of this work was to detect and interpret genetic backround for bread - making quality based on variations of HMW - GS in Triticum aestivum L. genetic resources and varieties originated from the Europe.

\section{MATERIAL AND METHODS}

We analyzed seed storage proteins, which were extracted from 108 genotypes of hexaploid wheat (Triticum aestivum L.) grain originating from five different geographical areas (Slovakia, Czech Republic, Hungary, Germany and France) of Europe. All samples were obtained from the collection of genetic wheat resources of the Gene Bank of Slovak Republic in Piešt'any. Seed storage proteins were isolated from the endosperm of intact, dry and mature single seeds. There were analysed one hundred individual grains from each genotype. Seed homogenization was carried out by grinding. Glutenins were extracted by standard referee method ISTA and were performed by discontinuous PAGE based on ISTA methodology (Wrigley, 1992) using the electrophoretic unit Protean II (BioRad). Protein fractions were stained by Coomassie Brilliant Blue $\mathrm{R}-250$. The separate gluten subunits were identified by the nomenclature of Payne and Lawrence (1983).

\section{RESULTS AND DISCUSSION}

During the last few years an increasing interest of wheat breeders for genetically adapted and diverse raw material can be detected, mainly influenced by need for quality traits, specific adaptability, and yield stability of wheat. Wheat landraces are varieties that were improved by farmers over many generations without the use of modern breeding techniques. Genetic erosion is a process linked with modern agriculture and implies that the normal addition and disappearance of genetic variability in a population is altered so that net change in diversity is negative (Gregová et al., 1997). Using electrophoretic analyses of wheat glutenins it is sometimes possible to detect new HMW - GS alleles also in landraces (van Hintum and Ellings, 1991; Tahir et al., 1996, Gregová et al., 1999; Juhász et al., 2001, Gregová et al., 2006).

One hundred and eight hexaploid wheat accessions originating from Slovakia (32 cultivars), Czech Republic (15), Hungary (14), Germany (18) and France (29) were evaluated for high molecular weight glutenin subunits using SDS - PAGE. Twelve different $G l u-1$ encoded allelic variants were identified among these 108 genotypes resulting from combination of 3 alleles of Glu $-1 A, 7$ of Glu - 1B and 2 of $G l u-1 D$ loci (Table 1). Also one novel allelic variant at the $G l u-1 B$ locus was identified. 
Table 1 Complete review of frequency of specific electrophoretic protein profiles within 108 wheat cultivars

\begin{tabular}{|c|c|c|c|c|c|}
\hline Country of origin & SVK & FRA & DEU & CZE & HUN \\
\hline Glu-1A0 & 25 & 22 & 13 & 13 & 4 \\
\hline Glu-1A1 & 4 & 6 & 5 & 2 & 5 \\
\hline Glu-1A2* & 3 & 1 & 0 & 0 & 4 \\
\hline Glu-1B7+8 & 4 & 6 & 1 & 7 & 3 \\
\hline Glu-1B6+8 & 1 & 6 & 8 & 1 & 0 \\
\hline Glu-1B17+18 & 0 & 6 & 2 & 0 & 0 \\
\hline Glu-1B7+9 & 23 & 7 & 7 & 7 & 10 \\
\hline Glu-1B7 & 0 & 2 & 0 & 0 & 0 \\
\hline Glu-1B20 & 1 & 1 & 0 & 0 & 1 \\
\hline Glu-1B6.5+7.5 & 0 & 1 & 0 & 0 & 0 \\
\hline Glu-1D2+12 & 7 & 18 & 3 & 1 & 2 \\
\hline Glu-1D5+10 & 23 & 11 & 15 & 14 & 12 \\
\hline
\end{tabular}

All three allelic variants were detected at the $G l u-1 A$ (Figure 1), the most frequent allele was $G l u-1 A O$ (null allele) in 77 lines (71 \%) and Glu - 1A1 which were found in 23 lines $(21 \%)$ that is consistent with the results of Oslovičová et al. (2010) research. The HMW - GS 2* of allele Glu - 1A2* appeared only in 8 lines (four Hungarian, three Slovakian and one French). Distribution of the HMW glutenin subunits revealed that advanced lines having subunit 1 or $2 *$ encoded by Glu $-1 A$ locus possess better bread-making quality attributes because of the linear relationship of these fragments with higher extensibility and better dough strength (Alvarez et al., 2009). The frequency of various allelic combinations is widely affected by the breeding strategies and the traits of preference.

High polymorphism of glutenin proteins was observed at the locus $G l u-1 B$ (Figure 2), where alleles 20 and 7 and allelic pairs $6+8,7+8,7+9$ and $17+18$ were

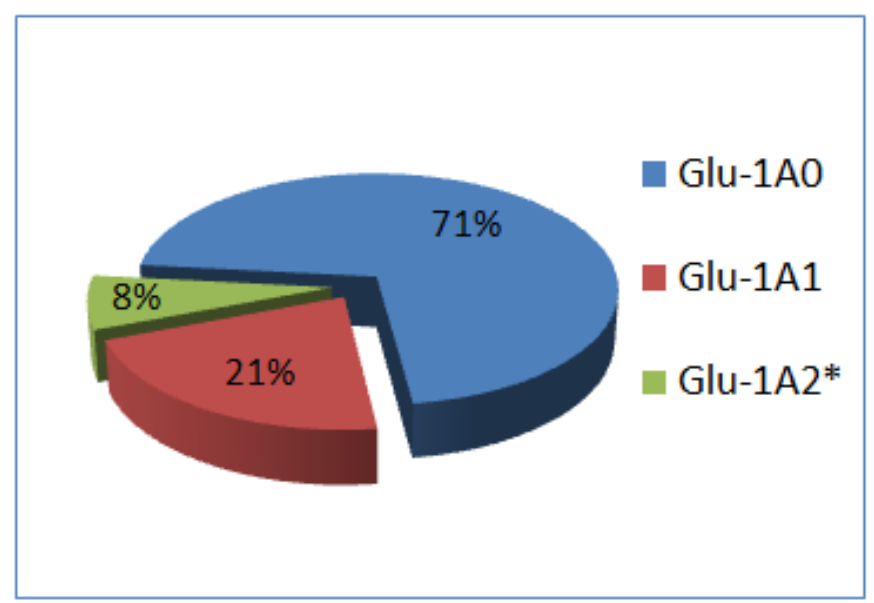

Figure 1 Allelic frequency at $G l u-1 A$ locus

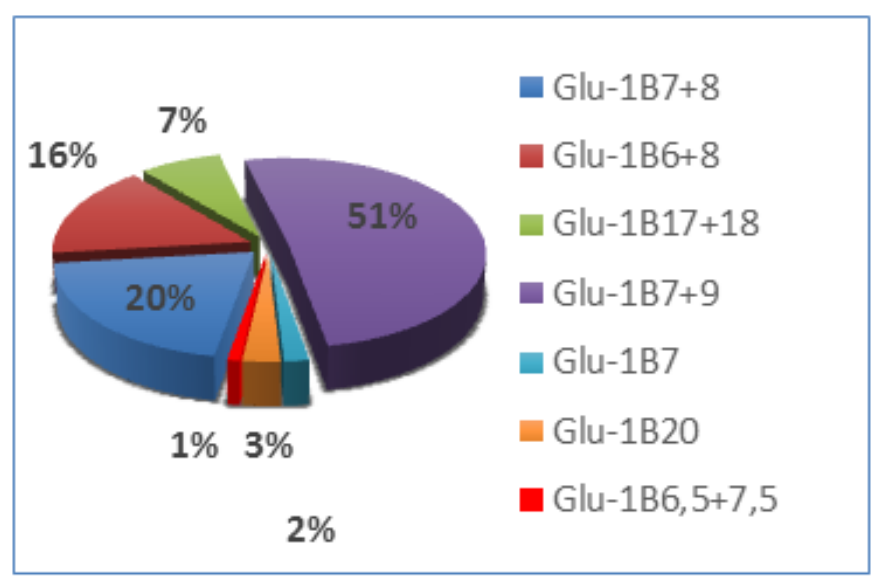

Figure 2 Allelic frequency at $G l u-1 B$ locus observed. For the $G l u-1 B$ locus, the allele $G l u-1 B 7+9$ was the most frequent $(51 \%)$ among the evaluated lines is associated with good bread - making quality (Gálová et al., 2009). The HMW - GS 7+8 (20\%), 6+8 (16\%) and 17+18 (7\%) were also detected on the $G l u-1 B$. The new allele at the $G l u-1 B$ was found in France cultivar Bagou. The comparative higher level of allelic diversity $(\mathrm{H})$ at the $G l u-1 B$ locus is attributed partly to allelic richness and to diverse parental lines possessing different genetic backgrounds. Earlier An et al. (2005), Li et al. (2009), and Moragues et al. (2006) observed higher diversity (H) at the $G l u-1 B$ locus in wheat.

The existence of two alleles at the locus $G l u-1 D$ was revealed; in fact $71 \%$ of them showed the subunit pairs $5+10$ correlated with good bread - making properties (Figure 3).

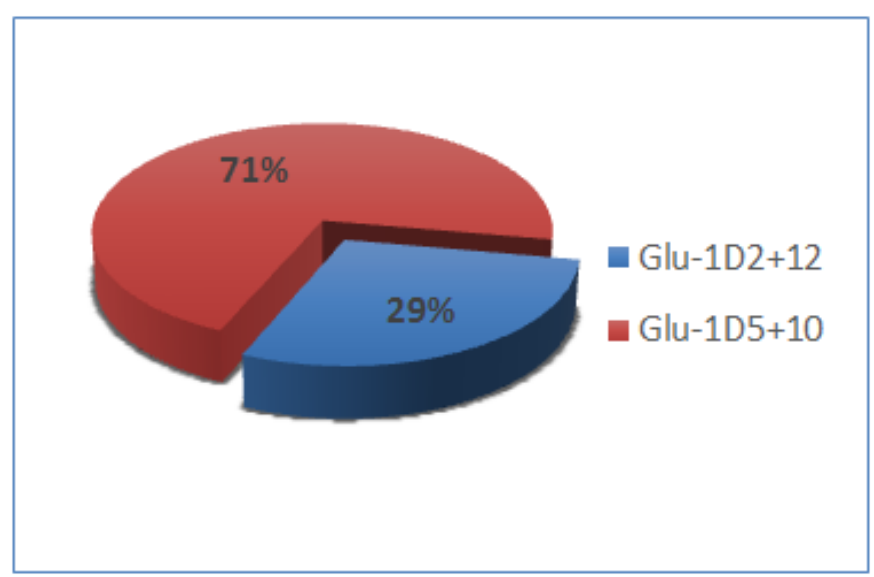

Figure 3 Allelic frequency at $G l u-1 D$ locus

Cereal breeding programs have been focused mainly on quality and quantity of production in last few decades which result to decreasing of genetic variability and narrowing of polymorphism. Therefore, growing genotypes of cereals are high productive with good quality, but their adaptability to environmental conditions and resistance to biotic and abiotic stress factors are on the low level (Chňapek et al., 2013).Therefore, landraces and old genotypes with interesting properties have to be involved into process of hybridization to find out new high molecular weight glutenin subunits.

\section{CONCLUSION}

Proteomics and seed storage protein analysis help us to understand polymorphism between different types of cereals as well as gene expression of individual proteins. High molecular weight glutenin subunits participate in wheat quality characteristics, mainly in baking quality. In this work we discovered novel HMW-GS 1Bx6.5 and 1By7.5 which we are going to describe more detailed with other analyses. This genotype will also make it possible to develop and use in breeding programs to screen lines for bread-making quality.

Acknowledgments: This work was supported by the Ministry of Agriculture and Rural Development of the Slovak republic: R\&D project „Genetic improvement of farm traits of important crops" $(50 \%)$ and co-funded by European Community under project no 26220220180: Building Research Centre „AgroBioTech" (50 $\%)$. 


\section{REFERENCES}

ALVAREZ, J.B., CABALERO, L., NADAL, S., RAMIREZ, M.C., MARTIN, A.. 2009. Development and gluten strength evaluation of introgression lines of Triticum urartu in durum wheat. Cereal Res. Comm., 37, 243 - 248. http://dx.doi.org/10.1556/CRC.37.2009.2.11

AN, X., QIAOYUN, L., YUEMING, Y., YINGHUA, X., HSAM, S.L.K, ZELLER, F.J. 2005. Genetic diversity of European spelt wheat (Triticum aestivum ssp. Spelta L. em. Thell.) revealed by glutenin subunit variations at the Glu-1 and Glu-3 loci. Euphytica, 146, 193 - 201 http://dx.doi.org/10.1007/s10681-005-9002-6

BEDÕ, Z., KÁRPÁTI, M., VIDA, G.,KRAMARIKKISSIMON, J. 1995. Good bread making quality wheat (Triticum aestivum, L.) genotypes with $2+12$ subunit composition at the Glu-D1 locus. Cereal Res. Comm., 23(3), 283 - 289.

CORNISH, G. B., PANOZZO, J. F., WRIGLEY, C. W. 1999. Victorian wheat protein families. In: OBrien, L., Blakeney, A. B. Ross, A. S. and Wrigley, C.W. (Eds.), pp. 183-188. Cereals 98. Proceedings of the 48th Australian Cereal Chemistry Conference. RACI: Melbourne, Australia. Genetics, 77, 57 - 64.

GÁLOVÁ, Z., CHŇAPEK, M., BALÁŽOVÁ, Ž., STEHLÍ́KOVÁ, B. 2009. Genetická diverzita prolamínových bielkovín vo vzt’ahu k pekárenskej kvalite pšenice. Acta fytotechnica et zootechnica., 12, 226 - 233. ISSN 1335 - 258X GREGOVÁ, E., HERMUNTH, J., KRAIC, J., DOTLAČIL, L. 1999. Protein heterogenity in European wheat landraces and obsolete cultivars. Genet. Resour. Crop Evol., 46, 521 - 528. http://dx.doi.org/10.1023/A:1008751815445

GREGOVÁ, E., HERMUNTH, J., KRAIC, J, DOTLAČIL, L. 2006. Protein heterogenity in European wheat landraces and obsolete cultivars: Additional information. Genet. Resour. Crop Evol., 51, 569 - 575. http://dx.doi.org/0.1007/s10722-006-0010-8

GUPTA, R. B., SINGH, N. K., SHEPHERD, K. W. 1989. The cumulative effect of allelic variation in LMW and HMW glutenin subunits on physical dough properties in progeny of two bread wheats. Theoretical and Applied Genet., 77 , 57 - 64. http://dx.doi.org/10.1007/BF00292316

CHŇAPEK, M., TOMKA, M., GÁLOVÁ, Z., BALÁŽOVÁ, Ž. 2013. Utilization of storage proteins polymorphism for differention of wheat, rye and triticale genotypes. Journal of Microbiology, Biotechnology and Food Sciences. 2(2), 2087 - 2098. ISSN $1338-5178$

JUHÁSZ, A., TAMÁS, L., KARSAI, I., VIDA, G., LÁNG, L., BEDÕ, Z. 2001. Identification, cloning and characterisation of a HMW - glutenin gene from an old Hungarian wheat variety, Bánkúti. Euphytica, 119, 75 - 79 http://dx.doi.org/10.1007/s00122-003-1292-2

LI, Y., CHENGYAN, H., XINXIA, S., QINGQI, F., GENYING, L., XIUSHENG, C. 2009. Genetic variation of wheat glutenin subunits between landraces and varieties and their contributions to wheat quality improvement in China. Euphytica, 169, 159-168. http://dx.doi.org/10.1007/s10681-009-9905-8 MACRITCHIE, F., DU CROS, D. L., WRIGLEY, C. W. 1990. Flour polypeptides related to wheat quality. Advances in cereal science and technology, $10,79-145$.

MORAGUES, M.J., ZARCO-HERNÁNDEZ, M., MORALEJO, A., ROYO, C. 2006. Genetic diversity of glutenin protein subunits composition in durum wheat landraces (Triticum turgidum L. var. durum) from the Mediterranean basin Genet. Resour. Crop Evol., 53, 993 - 1002. http://dx.doi.org/10.1007/s10722004-7367-3

OSLOVIČOVÁ, V., GÁlOVÁ, Z., CHŇAPEK, M., BALÁŽOVÁ, Ž. 2010. Identification of Triticum aestivum L., Triticum spelta L. and Triticum durum DESF. genotypes on the HMW-GS base. Plant, soil and environment., 56 (2), 82 - 86. ISSN $1214-1178$

PAYNE, P. I., LAWRENCE, G. J. 1983. Catalogue of alleles for the complex loci, Glu-A1, Glu-B1 and Glu-D1 which code for high-molecular-weight subunits of glutenin in hexaploid wheat. Cereal Res. Commun., 11, $29-35$.

PAYNE, P.I. 1987. Genetics of wheat storage proteins and the effect of allelic variation on bread - making quality. Ann Rev Plant Physiol., 38, 141 - 153 http://dx.doi.org/10.1146/annurev.pp.38.060187.001041

POGNA, N.E., MELLINI, F. 1986. Alla ricerca delle basi biochemiche e genetiche della qualita del glutine. L'Inform Agr, 42, 65 - 66

TAHIR, M., TURCHETTA, T. ANWAR, R., LAFIANDRA, D 1996.Assessment of genetic variability in hexaploid wheat landraces of Pakistan based on polymorphism for HMW glutenin subunits. Genet. Resour. Crop Evol., 43, 211 - 220. http://dx.doi.org/10.1007/BF00123273

VAN HINTUM, T.J.L., ELLINGS, A. 1991. Assessment of glutenin and phenolic diversity of Sirian durum wheat landraces in relation to their geographical origin. Euphytica, 55, $211-220$.

WEEGELS, P. L, HAMER, R. J., SCHOFIELD, J. D. 1996. Functional properties of wheat glutenin. Journal of Cereal Science, 23, $1-18$ http://dx.doi.org/10.1006/jers.1996.0001

WRIGLEY, C. W. 1992. Identification of cereal varieties by gel electrophoresis of the grain proteins. Seed Analysis. Berlin: Heilderberg, Springerverlag, 17 - 41 http://dx.doi.org/10.1007/978-3-662-01639-8_ 2 